\title{
Analisis Patronase Politik Terhadap Birokratisasi Pemerintahan Dalam Pemilihan Kepala Daerah Kota Padang
}

Oleh:

\author{
SHERLY ATHA WINANTI \\ , Jurusan Ilmu Politik, Fakultas Ilmu Sosial dan Ilmu Politik \\ Universitas Andalas, Padang \\ E-mail: sherlyatha08@gmail.com
}

\begin{abstract}
Abstrak
Persaingan di dalam suatu organisasi pemerintah yang mempunyai suatu jabatan selalu menimbulkan gesekan-gesekan negatif. Sumber dari segala hal tersebut dikarenakan tidak adanya kebijaksanaan birokrat dalam menjalankan tugas dan tanggung jawab yang profesional, efisiensi, netral, dan jujur. Pelaksanaan dalam sistem birokrasi ini tidak luput dari pandangan masyarakat yang mengenal bahwa orang-orang yang menduduki jabatan birokrasi selalu melayani masyarakat serta menjadi perantara antara partai politik dengan pemerintah. Sudah menjadi hal yang lumrah jika para birokrat selalu memakai sistem mutualisme, serta adanya hubungan timbal balik tanpa merugikan pihak yang satu dengan pihak yang lainnya. Pada pemberian jabatan dari atasan (patron) kepada bawahan (klien) ini selalu disertakan dengan nafsu yang tinggi dan marukh bahwa seseorang yang mempunyai jabatan tinggi maka dia juga harus keseimbangan atau balance dengan memiliki kekuasaan yang luas dan tinggi juga. Oleh karena itu perekrutan anggota birokrasi pada pemerintah tidak selalu melihat dari sisi kefungsionalan seseorang, namun karena pendukungan dari bawahannya. Pasti ada istilah yang selalu terpaku dalam benak dan pikiran seorang pejabat tinggi birokrasi, bahwa semakin kuat kekuasaan seseorang maka selalu ditandai dengan banyaknya bawahan atau staff yang dimilikinya terkhususnya di kota Padang. Metode yang digunakan dalam artikel ini adalah metode pennulisan dengan studi literasi yang bersumber dari sumber tertulis, berupa jurnal, artikel, majalah, internet, pustaka atau dokumen-dokumen yang relevan dengan permasalahan yang dikaji. Hasil penelitian dengan metode studi literatur ini adalah untuk menganalisis hubungan patron dan klien terhadap birokratisasi pemerintahan dengan dimensi adanya parkinson atau penyakit klasik yang belum dapat di atasi atau dihilangkan yang akan berdampak pada masyarakat luas.
\end{abstract}

Kata Kunci: Patronase, Birokrasi Pemerintah, Parkinson Birokrasi 


\begin{abstract}
Competition in a government organization that has a position always causes negative friction. The source of all this is due to the absence of bureaucrats' policies in carrying out professional, efficient, neutral and honest duties and responsibilities. Implementation in the bureaucratic system is not spared from the view of the public who know that people who occupy bureaucratic positions always serve the community and become an intermediary between political parties and the government. It has become commonplace for bureaucrats to always use a system of mutualism, as well as mutual relations without harming one party to the other. In giving positions from superiors (patrons) to subordinates (clients), it is always included with a high desire and marukh that someone who has a high position then he must also balance with a broad and high power as well. Therefore the recruitment of bureaucratic members in the government does not always look at the functional side of a person, but because of the support of his subordinates. There must be a term that is always fixed in the mind and mind of a high-ranking bureaucratic official, that the stronger a person's power is always marked by the number of subordinates or staff he has especially in the city of Padang. The method used in this article is the writing method with literacy studies sourced from written sources, in the form of journals, articles, magazines, internet, literature or documents that are relevant to the problem under study. The results of the study with this literature study method are to analyze the relationship between patrons and clients towards government bureaucratization with the dimensions of parkinsonism or classic disease that cannot be overcome or eliminated which will have an impact on the wider community.
\end{abstract}

Keywords: Patronage, Government Bureaucracy, Parkinson's Bureaucracy

\title{
PEDAHULUAN
}

\section{Latar Belakang}

Hubungan antara patron (atasan) dan klien (bawahan) telah menjalin suatu kerja sama yang bersifat saling mutualisme atau menguntungkan pihak yang satu dengan pihak yang lainnya. Pemberian jabatan tidak hanya dilakukan secara percumacuma, namun ada timbal balik yang membawa pengaruh besar terhadap keuntungan pemerintah untuk menguatkan ikatan di dalam suatu organisasi. Kerajaan birokrasi dapat saja dibangun dan didirikan oleh orang-orang sekitarnya, anak-anak, kelaurga besar, teman dekat, maupun yang memberikan manfaat besar bagi dirinya dimasa yang akan datang nanti. Patronase menjadi konstelasi politik yang memberikan pengaruh pada sektor politik, ekonomi dan sosial. Sektor politik memberikan kepercayaannya kepada para birokrat untuk dapat mengurus dan mengatur segala pelayanan yang dibutuhkan masyarakat. Hubungan rumit antara politisi menjadi gerbang utama masuknya patronase politik. Pasalnya kerap kali anggota birokrasi menjadi politisi yang seharusnya mereka memberikan pelayan publik, namun mereka menjadi pengatur suatu kebijakan dalam pemerintahan. Kekuasaan ganda inilah menjadi sumber penyakit klasik yang sulit untuk diatasi jika bukan dari dalam diri mereka masing-masing.

Lihat saja bagaimana sistem patronase ini selalu hadir dalam kontestasi politik dalam pemilihan kepala daerah kota padang contohnya, jabatan-jabatan yang akan diperebutkan tersebut sesungguhnya telah ditetapkan siapa yang akan mendapatkannya, karena calon pejabat tersebut merupakan orang-orang terdekat dari seorang pemimpin atau pejabat yang 
lebih tinggi dan mempunyai kekuasaan mengatur kemenangan calon yang ia inginkan. Oleh sebab itu, munculah sifat parkinson birokrasi yang mempunyai hawa nafsu, dan keinginan besar untuk memiliki staff dan bawahan yang banyak walaupun kita tidak tahu apakah staff tersebut memiliki fungsional yang profesional atau hanya mencari sebuah jabatan saja tanpa harus memenuhi tanggungjawab melayani masyarakat. Seringkali kita mendengar bahwa musim pemilukada adalah musim dimana birokrasi tepecah-belah, hal tersebut banyak terjadi baik di tingkat pusat maupun darerah dari pemilu-pemilu yang telah dilalui sepanjang sejarahnya begitupula yang terjadi di Kota Padang, jauh-jauh hari sebelum pemilukada dilaksanakan mereka para birokrat sudah sibuk dengan apa yang disebut dalam istilah di Padang "cari aman". ${ }^{1}$

Bagi para peminat dan pemerhati lingkungan, tentu sering anda melihat berbagai bentuk hubungan atau relasi yang antar manusia. Hubungan tersebut telah terjalin sejak zaman orde lama hingga zaman orde reformasi saat ini, salah satu relasi itu adalah hubungan patron-klien atau yang biasa kita sebut dengan patronase. Istilah patron bersal dari ungkapan bahasa spanyol yang secara etimologis berarti " bahwa seseorang yang memiliki kekuasaan, status, jabatan, dan pengaruh yang besar ( Usman, 2004:132). Sedangkan klien berarti bawahan atau orang yang dengan sukarela membantu pekerjaan pemerintah, walau mereka sebenarnya juga mendapatkan perjanjian mendapatkan jabatan dan kekuasaan yang mutlak serta tetap. Selanjutnya pola hubungan birokrasi dengan politisi tidak berjalan dengan sebaik-baiknya karena adanya perbedaan jenjang kedudukan

1 Rekha, Adji Pratama. 2017. Patronase Dan Klientalisme Pada Pilkada Serentak Kota Kendari Tahun 2017. Jurnal Wacana Politik. 2(1): 33-45. seseorang dalam pemerintahan pusat. Dapat pula kita perhatikan bahwa munculnya patronase itu karena adanya celah masuk kedalam yang sengaja maupun yang tidak disengaja oleh calonnya. Atau dapat pula kita artikan bahwa patron adalah orang yang berada dalam posisi untuk membantu klienkliennya (Scott,1983:14).

Pemberian pengaruh menjadi suatu entitas yang sangat ditunggu oleh klien dari patronnya untuk mendapatkan apa yang mereka inginkan dan menjadi pekerja dibawah pimpinan pemerintah. Hubungan rumit antara birokrat dan politisi ini merupakan momok tersendiri bagi panggung penampilan kekuatan bagi setiap pejabat tinggi negara. Namun, hal yang sangat dikhawatirkan dalam pelaksanaan wewenang dan tugas mereka masingmasing adalah ketika para birokrat tersebut menyelewengkan jabatan dan kekuasaan mereka dengan sesuka hati yang menyebabkan munculnya KKN (Korupsi, Kolusi, dan Nepotisme). Hingga saat ini permasalahan yang sebetulnya tidak rumit ini tidak terselesaikan, hanya saja kesadaran di dalam diri pejabat atau seorang individu itu yang sudah musnah dan hal tersebut akan menyulitkan serta merugikan masyarakat dan pemerintah untuk mengaturnya. Sejak kepemerintahan di tangan Presiden ke tiga Indonesia yakni Megawati Soekarno Putri, telah menciptakan adanya organisasi untuk memberantas korupsi, kolusi, dan nepotisme di Indonesia yang kita sebut sebagai KPK. Sangat disayangkan jika dalam kejadian patronase tersebut yang memberikan mutualisme antar individu tanpa progres yang formal dan netral ini, tidak digolongkan dalam kolusi atau sebuah sikap yang membuat kesepakatan dan perjanjian secara tersembunyi yag disertakan adanya fasilitas tertentu atau disebut sebagai pelicin. 
Manifestasi keuntungan dilakukan sebagai penyaluran harta berharga yang memberikan keuntungan bagi kerajaan pejabat. Dalam sebuah kedudukan yang menggunakan teorinya weber, bahwa dalam sistem pemerintahan itu pasti akan ada hirarki atau tingkatan jabatan yakni dari yang paling bawah hingga yang paling atas (patron). Pelebaran kekuasaan ini merupakan kesalahan kita bersama, kesalahan dari implementasi sebuah kebijakan yang tidak sesuai dengan keadaan realita masyarakat. Legislatif dan eksekutif telah merumuskan suatu peraturan dan kebiijakan untuk dipatuhi dan dihormati. Memang bukan salah peraturannya, namun karena ke-egoisan serta nafsu yang besar untuk memiliki segalanya walau menggunakan berbagai cara, termasuk juga dengan cara menipu individu atau masyarakat.

Artikel ini akan menjelaskan tentang bagaimana analisis patronase politik terhadap birokrasi pemerintah dalam pemilihan kepala daerah Kota Padang. Tulisan ini di dasarkan pada 2 asumsi: (1) Patronase politik menjadi suatu momok yang sentral dalam pemilihan kepala daerah untuk menjadi anggota birokrasi pemerintah yang melayani segala kebutuhan dan pelayanan publik; (2) Patronase politik sangat dipengaruhi adanya parkinson klasik yang menjadi adat-istiadat turun temurun dari para birokrat terdahulu.

\section{Rumusan Masalah}

Adapun rumusan masalah yang dapat dikemukakan dalam analisis patronase politik pada birokrasi pemerintah terhadap pemilihan kepala daearah adalah sebagai berikut:

1) Bagaimana analisis patronase politik dalam birokrasi pemerintah terhadap pemilihan kepala daerah Kota Padang?
2) Bagaimana dampak adanya patronase politik dalam birokrasi pemerintah terhadap pemilihan kepala daerah Kota Padang?

3) Apakah ada keterkaitan antara patronase politik dengan penyakit parkinson dalam pemilihan kepala daerah Kota Padang?

\section{Tujuan Penelitian}

Adapun tujuan dari penelitian ini sebagai berikut:

1) Untuk mengetahui dan memahami analisis patronase politik dalam birokrasi pemerintah tehadap pemilihan kepala daerah Kota Padang.

2) Untuk mengetahui dan memahami dampak adanya patronase politik dalam birokrasi pemerintah terhadap pemilihan kepala daerah Kota Padang.

3) Untuk mengetahui dan memahami adanya keterkaitan antara patronase politik dengan penyakit parkinson dalam pemilihan kepala daerah Kota Padang.

\section{METODE PENELITIAN}

\section{Jenis Penelitian}

Jenis data yang digunakan dalam penelitian ini meliputi data kualitatif yaitu mendeskripsikan data apa adanya dan menjelaskan data atau kejadian dengan kalimat penjelasan secara kualitatif, sebagaimana diungkapkan oleh Sugiyono (2012) metode kualitatif untuk mendapatkan data yang mendalam, dan suatu data yang mengandung makna secara signifikan yang dapat mempengaruhi substansi penelitian.

\section{Tempat dan Waktu}

Peneliti mendapatkan data secara data sekunder, tanpa harus turun tangan langsung meminta data mengenai adanya patronase politik dan penyakit parkinson birokrat dalam pemilihan kepala daerah. 
Oleh karena itu, peneliti tidak bisa memaparkan tempat dan waktu pengambilan data tersebut.

\section{Prosedur Penelitian}

Prosedur penelitian merupakan langkah-langkah atau urutan yang harus dilalui atau dikerjakan dalam suatu penelitian. Langkah pertama yang dilakukan dalam penelitian ini adalah melakukan studi kepustakan (studi Literatur), selanjutnya merumuskan masalah, menentukan objek penelitian, mengumpulkan data, mengolah dan menyajikan data, menganalisis data atau menarik kesimpulan, serta membuat kesimpulan.

\section{Metode Pengumpulan Data}

Pengumpulan data merupakan satu tahap yang sangat menentukan terhadap proses dan hasil penelitian yang akan dilaksanakan. Pengumpulan data yang digunakan dalam penelitian ini adalah metode dokumentasi. Metode dokumentasi merupakan catatan peristiwa yang sudah berlalu. Dokuen bisa berbentuk tulisan, gambar atau karya-karya monumental dari seseorang. Dokumen yang berbentuk tulisan misalnya catatan harian, sejarah kehidupan (life histories), cerita, biografi, peraturan, dan kebijakan. Dokumen yang berbentuk gambar misalnya foto, gambar hidup, sketsa dan lain-lain. Dokumen yang berbentuk karya misalnya karya seni, yang dapat berupa gambar, patung, film, dan lain-lain. Studi dokumen merupakan pelengkap dari penggunaan metode observasi dan wawancara dalam penelitian kualitatif (Sugiyono, 2013:240).

\section{Teori Yang Digunakan}

Pada penelitian yang saya teliti saat ini menggunakan beberapa teori dasar mengenai birokrasi yang "seharusnya memberikan pelayanan" namun realitanya di Indonesia, masyarakat yang membayar mereka, memberikan kepercayaan kepada dan memberikan pelayanan kepada pejabat birokart. Tanpa kita sadari telah menggorogoti tubuh birokrasi itu sendiri, kesadaran yang teralihkan karena material menggiurkan yang di janjikan. Perbaikan dari teori ini tidaklah semudah apa yang dibayangkan, karena legalitas hukum, produktivitas masyarakrat, serta implementasi yang buruk dan tidak profesional. Oleh karena itu, peneliti menggunakan teori sebagai berikut:

1. Teori Patronase Politik

2. Teori Birokrasi Pemerintah

3. Teori Penyakit Parkinson

4. Teori Pilkada (Pemilihan Kepala Daerah)

Secara umumnya dalam organisasi sektor publik, akan dinilai baik jika penggunaan teori diatas dapat digunakan dalam memperbaiki atau setidaknya kita dapat menyadari bahwa yang selama ini kita lakukan itu tidak benar dan harus direformasi atau dikonstruksi ulang.

\section{TINJAUAN PUSTAKA}

\section{Patronase Politik}

Politik merupakan hal yang tidak dapat dipisahkan dari kehidupan manusia, terkhususnya sejak zaman orde baru hingga zaman reformasi saat ini, secara sadar atau tidak sadar manusia harus mengakui keberadaanya sebagai insan yang hidup dibawah dunia perpolitikan dan diatur oleh pemerintah. Jika pun ia bukan sebagai subjek, maka ia pasti nantinya menajdi objek penelitian orang lain oleh seorang peneliti. Politik selau memiliki hubungan yang erat dengan kekuasaan dan penguasa. Oleh karenanya, manusia akan saling berinteraksi dan bekerja sama untuk mencapai suatu tujuan bersama melalui 
suatu mekanisme politik untuk memperoleh, mempenagruhi, mempertahankan, dan mendistribusikan kekuasaan. Namun sayangnya, kadang kala hubungan hubungan politik dalam pencapaian suatu kekuasaan yang terjadi bersifat patronase politik.

Patronase merupakan ajang tradisiturun temurun dari nenek motang yang memberikan jabatan dan kekuasaan hanya kepada orang-orang terdekat dan keluarganya. Adanya rasa egoisme yang tinggi menyebabkan patronase ini dinilai sangat buruk hingga tidak mencerminkan demokrasi sesuai dengan Undang-undang Dasar 2945. Pembagian jabatan ini dapat berjalan kepada rekan terdekat dengan berbagai transaksi yang menguntungkan satu sama lain. Patronase juga bisa berupa uang tunai atau barang yang didistribusikan kepada pemilih yang berasal dari dana pribadi (misalnya, dalam pembelian suara atau biasa dikenal dengan money politics dan vote buying) atau dana-dana publik (misalnya, proyekproyek pork barrel yang di biayai oleh pemerintah). ${ }^{2}$

Patronase biasanya didefinisikan sebagai bentuk kekuasaan yang memebrikan gambaran tugas dan fungsi masing-masing pada mesin birokrasi di semua tingkatan. Akan tetapi, dalam pengertian yang lebih khusus, patronase berarti pendistribusian berbagai sumber daya yang berharga, yaitu pensiun, lisensi, atau kontrak publik berdasarkan kriteria politik, dan ada patron yang memiliki kekuasaan serta ingin mempertahankannya, dan di sisi lain ada klien yang berada pada posisi subordinat, meski tidak berarti tanpa daya sepenuhnya atau kekuarangan sumber

2 Rekha Adji Pratama. 2017. Patronase Dan Klientalisme Pada Pilkada Serentak Kota Kendari Tahun 2017. Jurnal Wacana Politik. 2(1): 33-45. daya ( Pasquito, 2000:736). Kemudian menurut Pasquino (2000: 737), patronase sering kali menimbulkan korupsi. Sumber-sumber publik dipakai sebagai sumber penyuapan. Hal itu tentunya berbeda dengan birokrasi di Eropa Barat yang tipe birokrasinya cenderung birokrasi yang rasional.

Masyarakat luas memerlukan tenaga yang mempunyai relativitas tinggi guna mencapai dan mewujudkan keinginan serta cita-cita kita bersama. Perwujudan pasti diiringi dengan usaha dan kejujuran pada diri masing-masing dan kepada orang lain yang bersifat transparan jika hal tersebut masih berhubungan dengan urusan negara dan masyarakat. Aktifnya suatu pemerintahan dapat dilihat dari segi fungsinal birokrat yang bekerja di sekeliling kita untuk melayani masyarakat, jika birokrat tersebut tidak memiliki tugas yang netral dan profesional maka dapat kita nilai bahwa kota yang buruk pasti memiliki pegawai yang buruk juga, dan sebaliknya jika kota tersebut asri, damai, dan menjalankan tanggung jawabnya dengan profesional maka kota tersebut akan jadi lebih baik. Legalitas merupakan suatu kebebasan bagi individu namun masih dalam batasan yang diatur dalam Undangundang.

Jika dilihat dari sisi legalitas tadi, maka jika kita sangkut pautkan dengan urusan dunia perpolitikan maka kebebasan individu ini menjadi peran utama dalam negara demokrasi. Negara yang memberikan kebebasan bagi setiap umatnya yang mengikuti segala aturan dan kebijakan yang telah di sepakati bersama, namun masih sesuai dengan asas-asas yang berlaku. Serta negara yang memberian keadilan rakyat yang sama rata, pernyataan tadi dimaksudkan bahwa setiap individu baik pejabat tinggi dari pemerintah, pegawai dengan tingkat 
jabatan sedang, rendah hingga ke dalam urusan masyarakat.

Dari definisi menurut para ahli yang telah diuraikan diatas dapat disimpulkan bahwa patronase politik adalah suatu paradigma yang tidak sengaja tercipta karena adanya perselisihan atau gesekan yang menimbulkan efek negatif serta merupaka bagian dari teori Max Weber mengenai tingkatan hirarki jabatan di dalam birokrasi pemerintah. Tanpa adanya perubahan atau reformasi yang di formasikan dalam bentuk patron (pemimpin) dan klien (staff). Dalam rangka membangun dan memastikan hubungan politisi dan birokrat baik-baik saja, maka pemerintah mengeluarkan azas yang memberikan hukuman kepada penjahat atau pelaku pidana baik itu kepada bawahan maupun kepada atasan atau pimpinan. Biasanya yang selalu bertindak curang dan egois adalah seorang pemimpin dalam birokrasi, yang mana mereka masih belum puas untuk mendapatkan kekuasaan yang lebih besar dan kuat.

Salah satu contohnya, yakni seorang pegawai di kantor A yang mempunyai jabatan sedang atau hanya sebagai staff biasa, namun ketika ia melihat orang lain yang lebih sukses darinya, maka ia pun melakukan kecurangan dengan berbagai cara yang dihalalkannya. Jika kita melihat dari sisi implementasi hukumnya, di Indonesia hukuman yang didapatkan oleh seorang pejabat tinggi, maka ia hanya mendapatkan penjara yang lebih ringan atau membayar denda saja, secara finansial-Nya mereka pasti mampu membayar berapapun denda yang akan mereka bayar hanya untuk mendapatkan kebebasan dan membersihkan nama mereka. Kemudian kita lihat dari sisi pegawai biasa yang mendapatkan hukuman yang berat serta denda yang terbilang cukup besar, apalagi bagi orang-orang kena sial atau korban fitnah, ia takkan mampu membayar dendanya, maka orang-orang kecil tersebut hanya bisa pasrah terhadap nasib yang akan dilaluinya.

Begitupun dengan keadaan pemilihan kepala daerah Kota Padang yang ikut menyalurkan beberapa calon pejabat politisi pemerintah yang akan menjadi penyalur aspirasi masyarakat. Baik dari pusat hingga ke daerah-daerah selalu menajdi entitas tersendiri untuk memeriahkan rangkaian pemilu namun masih memiliki kesamaan yang selalu turun-temurun dari nenek moyang hingga calon generasi y saat ini. Pemilihan kepala daerah selalu dilaksanakan dengan adanya beberapa calon walikota sebagai pejabat tinggi suatu wilayah tertentu atau kota. Dalam pemilu, ketika calon yang diusung tersebut menang maka akan ada sifat mutualisme antara yang satu dengan yang lainnya. Tentu saja hal tersebut juga disertai dengan adanya material yang mencukupi untuk mendapatkan suatu jabatan yang di inginkan. Maka akan terbentuklah kerajaan hirarki kedudukan yang dipimpin oleh pejabat tinggi suatu birokrat yang pada umumnya anak-anak pejabat nantinya akan mendapatkan upeti dari orang tua mereka masing-masing tanpa harus berusaha keras untuk mendapatkan pekerjaan nantinya.

\section{Birokrasi Pemerintah}

Birokrasi berasal dari kata bureaucracy, biro adalah meja dan kratein adalah pemerintahan yang jika digabungkan menjadi meja pemerintahan. Jadi birokasi adalah suatu organisasi yang dibentuk dari berbagai kepentingan individu dan bergabung membentuk suatu kepentingan bersama sesuai dengan peraturan Undang-Undang Republik Indonesia yang memiliki hirarki atau tingkatan dalam bentuk jabatan dan gaji sesuai dengan tugas serta tanggung jawab masing-masing individu para birokrasi, 
terkhususnya pemimpin birokrat atau pejabat tinggi negara yang mempunyai tugas paling berat dan paling ringan serta ia mendapatkan hasil dari kerja keras bawahannya (staff). Secara etimologi (bahasa) birokrasi adalah cara pemerintah yang dijalankan oleh pegawai bayaran yang tidak terpilih oleh rakyat; cara pemerintah yang sangat dikuasai oleh kaum pegawai negeri; maka dapat dikatakan jika birokrat itu seorang pegawai kantoran yang memiliki tanggung jawab. ${ }^{3}$ Kebiasaan masyarakat Indonesia itu yaitu selalu mengikuti budaya dan adat dari zaman nenek moyang hingga saat ini, baik dari budaya yang memberikan pengaruh baik maupun budaya yang memberikan pengaruh buruk atau yang dapat meruntuhkan sistem demokrasi kita yang telah ada ditetapkan sejak orde reformasi.

Pada era reformasi ini, pembahasan tentang birokrasi maka persepsi orang adalah birokrasi pemerintah. Birokrasi pemerintah seringkali diartikan sebagai officialdom atau kerajaan pejabat. ${ }^{4}$ Suatu kerajaan pemerintah ini mempunyai tatanan yang polanya dibentuk oleh pemerintah itu sendiri. Dalam penjabatan suatu birokrat itu memiliki yurisdiksi yang jelas, ${ }^{5}$ sehingga mereka mempunyai tujuan dan sasaran jelas untuk dicapai bersama. Penyerahan wewenang dari pejabat tinggi ke pejabat tinggi lainnya terjadi dengan begitu saja tanpa harus ada pertimbangan dan persetujuan dari bawahan atau staffnya. Sebab mereka memdapatkan gaji berdasarkan keahlian dan kompetensinya dan atas izin atasan. Karena tanpa seizin pimpinan tinggi negara melarang, maka gaji terhadap karyawan tersebut akan terhambat pencairannya. Dengan keberadaan negara

\footnotetext{
${ }^{3}$ Yusrialis. 2012. Budaya Birokrasi Pemerintahan. Jurnal Sosial Budaya. 9(1): 81-108..

4 Ibid, hlm. 90

5 Loc.cit.
}

pejabat ini menjadi ketakutan bagi masyarakat karena sifat patronase yang telah mengakar rumput.

Pada pembahasan birokrasi ini sudah tidak asing lagi bagi para ahli dan sering menjadi bahan pembicaraan. Munculya perdebatan yang sengit antara pemahaman dari Karl Marx dengan pemikiran Hegelian mengenai birokrasi. Karl Marx mulai memberikan kritikan tajam kepada konsep pemikiran hegel mengenai birokasi. Sedagkan menurut Hegel, birokrasi itu berperan aktif sebagai penguhubung antara pemerintah dengan masyarakat. Sehingga birokrasi dianggap sebagai pahlawan oleh masyarakat. Hegel menilai bahwa birokrasi seharusnya melayani kepentingan umum, karena kenyataan kebijaksanaan negara sering kali hanya menguntungkan sekelompok orang saja dalam suatu masyarakat. ${ }^{6}$ Selain dari pemikiran diatas, tercantumlah pemikiran Weberian yang mengatakan bahwa patronase itu tidak akan pernah berpihak pada tujuan umum/ bersama, ia hanya mendahulukan kepentingan pribadi sehingga budaya patronase ini tidak akan jauh dari birokrasi atau birokrat negara. Pada oemahaman inilah yang menjadi tolak ukur dari pemahaman birokrasi yang seharusnya. Dalam hal ini, jelas masa depan dan kepentingan birokrasi menurut konsep marx pada tingkat tertentu menjalin hubungan sanagt intim dengan kelas yang dominan dalam suatu negara Ismail, 2009: 15). ${ }^{7}$

Menurut Marx Weber, ia mengatakan bahwa birokrasi muncul semata-mata hanya pelengkap dan mendukung pemerintah dalam segala hal. Model birokrasi Weberian yang selama ini dipahami merupakan sebuah mesin yang

\footnotetext{
6 M. Adian Firmas. 2016. Politik Dan Birokrasi: Masalah Netralitas Birokrasi Di Indonesia Era Reformasi. Jurnal Review Politik. 6(1): 160194.

${ }^{7}$ Loc.cit.
} 
disiapkan untuk menjalankan da mewujudkan tujuan-tujuan yang ingin dicapai. Dengan demikian setiap pegawai dalam birokrasi pemerintah merupakan penggerak dari sebuah mesin yang tidak mempunyai kaitan dengan kepentingan pribadi. ${ }^{8}$ Memang birokrasi itu bersifat elastis namun menjadi pembawa pengaruh besar terhadap perkembangan negara, yang dimana berbagai lingkungan yang sangat kental akan keegoisan pejabat untuk memiliki kekuasaan besar dan tidak boleh direbut oleh orang lain, selain dari rekan atau keluarga yang dikenalnya, jadi jika diliat secara logika, birokrasi itu tidak boleh dicampurtangankan oleh kelompok patron. Seperti yang ditawarkan oleh Max Weber bahwa: ${ }^{9}$

1. Individu pejabat secara personal bebas, akan tetapi dibatasi oleh jabatannya manakala ia menjalankan tugas-tugas atau kepentingan individual dalam jabatannya. Pejabat tidak bebas menggunakan jabatannya untuk keperluan dan kepentingan pribadinya termasuk keluarganya.

2. Jabatan itu disusun dalam tingkatan hirarki dari atas ke bawah dan ke samping. Konsekuensinya ada jabatan atasan dan bawahan, dan adapula yang menyandang kekuasaan lebih besar dan ada yang lebih kecil.

3. Tugas dan fungsi masing-masing jabatan dalam hirarki itu secara spesifik berbeda satu sama lain.

4. Setiap pejabat mempunyai kontrak jabatan yang harus dijalankan. Uraian tugas masing-masing pejabat merupakan domain yang menjadi wewenang dan tanggung jawab yang harus dijalankan dengan kontrak.

8 Ibid, hlm 164

9 Ibid, hlm 166-167
5. Setiap pejabat diseleksi atas dasar kualifikasi profesionalitasnya, idealnya hal tersebut dilakukan melalui ujian yang kompetitif.

6. Setiap pejabat mempunyai gaji termasuk hak untuk menerima pensiun sesuai dengan tingkatan hirarki jabatan yang disandangnya. Setiap pejabat bisa memutuskan untuk keluar dari pekerjaannya dan jabatannya sesuai dengan keinginannya da kontrakya bisa diakhiri dalam keadaan tertentu.

7. Terdapat struktur pengembangan karier yang jelas dengan promosi berdasarkan senioritas dan merita sesuai dengan pertimbangan yang obyektif.

8. Setiap pejabat sama sekali tidak dibenarkan menjalankan jabatannya dan resources instansinya untuk kepentingan pribadi dan keluarganya.

9. Setiap pejabat berada di bawah pengendalian dan pengawasan suatu sistem yang dijalankan secara disiplin (Thoha, 2014; 19).

Penjelasan setiap bagian dari tipe birokrasi yang bagis bagi Weberian dapat menjadi batu loncatan yang efektif dan efisien jika dijalankan oleh Pemerintah dan rekan-rekannya. Pada penjabaran diatas dapat diartikan bahwa pemikiran weberian bersifat kebutuhan/ biro. Suatu biro merupakan jawaban yang rasional terhadap serangkaian tujuan yang telah diterapkan. ${ }^{10}$

Penjelasan patronase diatas menimbulkan berbagai dampak buruk terhadap setiap adanya kegiatan birokrasi di pemerintah, seperti pemilihan kepala daerah, pemilihan presiden atau lain halnya. Merealisasikan suatu kebijakan dan Undang-Undang itu tidaklah

10 Ibid, hlm 7 
gampang, karena kita harus melihat dari segi kondisi dan situasi masyarakat yang semakin mengarah kepada teori ke baratbaratan, walau sebelumnya negara ini mengikuti aliran timur. Pemilihan kepala daerah selalu dilakukan sekali dalam lima tahun, dan di awasi oleh pejabat birokrasi, yang sesungguhnya pegawai birokrat ini tidak begitu peduli dengan hasil, kegiatan dan output yang terjadi, mereka hanya memperdulikan gaji dan uang tambahan karena telah membantu masyarakat serta meringankan beban pekerjaan yang seharusnya dilaksanakan bersama. Calon pemilukada ini dapat dipastikan akan mendapatkan persentase yang besar apabila mereka dapat mengambil hati masyarakat terutama pada pejabat tinggi negara birokrasi yang nantinya akan memberikan kewenangan dan tugas sesuai dengan landasan yang dimilikinya. Oleh karena itu dari tingkat bawah ke tingkat atas sangat berpengaruh pada tingkat kelancaran urusan daerah dalam pemerintahan. Setiap jabatan yang dimiliki seseorang mempunyai tanggung jawab masing-masing, ter-khususnya bagi para pelayan publik yang melayani masyarakat untuk dapat berpartisipasi dalam pemilihan umum kepala daerah ini. Jika salah satu unsur penting dalam pilkada ini berkurang atau hilang, maka kegiatan yang wajib ini bisa hilang kepercayaan masyarakat terhadap pemerintah.

\section{Parkinson Birokrasi}

Secara umumnya masyarakat kurang memiliki pengetahuan tentang adanya penyakit atau kebiasaan dari orangorang pejabat negara, karena publik di alihkan perhatiannya kepada segala pemakaian kekuasaan dan tingkatan birokrasi dalam pemerintahan saja. Tabiat busuk dari seorang birokrat inilah yang nantinya menjadi bibit berkembangnya perilkau Korupsi, Kolusi, dan Nepotisme (KKN). Revolusi dari tingkatan inilah menjadi pemicu munculnya kebiasaan dan budaya yang secara tidak langsung akan turun temurun kepada anak cucu atau generasi penerus bangsa. Oleh karena penyebab ketidaksadaran perilaku ini menimbulkan pemicu konflik yang berhubungan dengan struktural fungsionalis dari birokratis itu sendiri. Konsep ini menjadi isu sentral bagi dikalangan pejabat tinggi pemerintah, yang terus menerus di bahas da di reformasi untuk mencapai suatu perubahan ke arah yang lebih baik, namun pada kenyataannya konsep ini semakin menyebar dan sudah di maklumi oleh kerajaan negara. Tanpa adanya perilaku ini, maka seorang pejabat tinggi negara atau seorang atasan tidak akan mendapatkan jaminan adanya petahana yang bertahan lama, semakin lama pasti nantinya akan digulingkan atau diturunkan dari jabatan yang sedang ia jalani saat ini.

Parkinson itu berasal dari kata metodologi "parkinsonisasi" yang dikemukakan oleh Hans-Dieter Ever dan Tilmen Schiel (1990) yang mengatakan bahwa birokrasi yang kian menjauhi praktik kerja profesional, efisiensi, dan melayani. ${ }^{11}$ Secara umum parkinson tidak dapat lepas dari birokrasi. Salah satu hal pokok yang menjadi sorotan adalah adanya kegiatan yang memperbanyak jumlah orang yang terlibat di dalam birokrasi, hal ini dilakukan bukan lantaran kebutuhan fungsional dari birokrasi tersebut, namun berdasarkan untuk memperbanyak klienkliennya yang akan mengikuti segala kehendaknya.

Fenomena parkoinson ini juga memiliki hubungan erat pada struktur dan sistem dari birokrasi yang dijalankan pejabat birokrat. Mengapa struktur ini

\footnotetext{
${ }^{11}$ Dalam artikel "Kabinet Parkinson" yang diunggah melalui laman web http://nasional.kompas.com
} 
menjadi salah satu acuan dalam melihat tambunnya birokrasi, karena strukturalisme berusaha menemukan agenda-agenda yang tersembunyi, aturanaturan permainan yang menentukan aksi. 12

Menjamurnya keinginan dari patron atau atasan untuk memiliki banyak pegawai bawahannya itu memberikan dampak yang positif bagi masyarakat yang merasa mempunyai hubungan dengan pejabt tinggi daerah pada saat itu. Seperti anak pejabat, anak pengusaha, keluarga, teman, serta keluarga yang jauh ingin mendapatkan kedudukan itu. Dalam tingkatan hirarki jabatan itu mempunyai sifat dasar rakus yang tak mampu untuk dibendung apabila telah melihat dan tergiur akan materi/ dana yang akan diberikan, oleh karena itu semakin tinggi jabatan seseorang maka semakin banyaklah pegawai bawahannya atau staff biasa, karena jika ingin mendapatkan legitimasi kekuasaan yang kuat, mereka menganggap bahwa harus banyak juga pendukung bawahannya. Walaupun pejabat tinggi birokrasi ini tidak melihat dan memilih bawahannya dari segi fungsional yang bersifat netral, profesional, dan diduktif terhadap tugas serta tanggung jawab yang harus dipikulnya.

\section{PENUTUP}

\section{Kesimpulan}

Negara Indonesia menjadi salah satu negara penganut sistem demokrasi, yang mempunyai dedikasi bahwa setiap individu atau kelompok wajib diberikan kebebasn dan keadilan tanpa ada yang termarginalisasi atau terpinggirkan. Salah satu konstestasi politik sekali dalam lima tahun selalu diwarnai dengan lika-liku kejadian yang membuat kegiatan ini

12 Apter, David E. 1985. Pengantar Analisa Politik. LP3ES, Jakarta. HIm. 371 menjadi sedikit terhambat. Kegiatan itu biasa disebut pemilihan kepala daerah (Pemilukada) di Kota Padang yang seperti sama-sama kita ketahui bahwa pemilihan pemilukada sebentar lagi akan diselenggarakan. Semua calon kepala daerah nantinya akan melalui proses yang panjang dan rumit, dikarenakan oleh pegawai atau pejabat birokrasi yang mengatur dan mengawasi pemilukada ini tidak melalui pemilihan pegawai yang profesionalitas, netral, dan memiliki tanggung jawab yang penuh. Oleh karena itu, ada saja alasan yang sengaja dimanipulasi, dan pegawai birokrasi tersebut tetap mendapatkan gaji yang utuh.

Dalam pemilihan kepala daerah ini dipengaruhi karena adanya partisipasi masyarakat, voting suara publik, hingga sosialisasi calon pejabat kepada masyarakat. Terkecuali bagi calon kepala daerah yang sebelumnya sudah menduduki jabatan yang sama, maka ia mendapatkan petahana yang lebih kuat untuk mendapatkan persentase kepercayaan masyarakat. Untuk mempertahankan petahana dan kekuasaan seorang pejabat yang mencalonkan diri lagi, maka ia menminta bawahannya untuk mendukung dirinya atau secara tidak langsung untuk memilihnya dengan cara mengancam para staffnya. Dari penjelasan diatas menggunakan konsep patronase, yakni adanya suatu organisasi patron dan klien atau sering disebut sebagai atasan dan bawahan. Atasan selalu mempunyai kekuasaan dan kekuatan untuk memenuhi segala keinginan pribadinya, secara sadar atasan tersebut tidak memiliki rasa kepedulian atau kepentingan publik.

Manifestasi dari keinginan atasan tersebut didasari atas kebudayaan dan perilaku dari pejabat yang sebelumnya selalu berperilaku yang tidak baik dan niat yang tidak netral. Kebiasaan tersebut 
dinamakan penyakit parkinson, penyakit ini menjelaskan bahwa patron memiliki keinginan yang berlebihan, yakni di dalam fikirannya bahwa seorang pejabat negara itu semakin ia memiliki bawahan atau staff yang banyak, maka ia memiliki kekuasaan yang kuat dan besar di mata masayrakat. Pejabat tinggi negara memikirkan bahwa akan memalukan jika tidak memiliki bawahan. Demi mendapat bawahan atau pegawai yang banyak maka pejabat itu akan menggunakan berbagai cara, walaupun yang dipilih tersebut tidak memiliki keprofesionalitasan seseorang.

\section{SARAN}

Dilihat dari permasalahan yang ada, dapat ditarik sebuah makna kerjasama aktor itu seimbang, maka dari itu seharusnya ada mekanisme kontrol dari pemerintah. Bagi masyarakat untuk mendapatkan pelayanan yang baik juga harus dilandasi dengan hubungan baik antara patron dan klien. Adanya kebiasaan parkinson inilah yang harus diperbaiki dan direformasi karena tidak memberikan dampak yang positif di dalam kegiatan pemerintah. Karena penyebab dari segala kegiatan KKN ( Kolusi, Korupsi, dan Nepotisme) inilah yang harus dihindari oleh pegawai birokrasi, dan juga dengan lembaga KPK maka birokrasi yang memiliki jabatan tinggi negara harus menjalankan tugas dan fungsi mereka masing-masing sesuai dengan keahlian mereka. Oleh sebab itu, sebaiknya penyakit parkinson ini dihilangkan secara perlahan-lahan. Tanpa adanya kebiasaan buruk ini, maka dipastikan keadaan sistem politik didalam negara akan membaik dari hari-kehari.

\section{DAFTAR PUSTAKA}

Rekha Adji Pratama. 2017. Patronase Dan Klientalisme Pada Pilkada Serentak Kota Kendari Tahun 2017. Jurnal Wacana Politik. 2(1): 33-45.

Yusrialis. 2012. Budaya Birokrasi Pemerintahan. Jurnal Sosial Budaya. 9(1): 1-28.

M. Adian Firmas. 2016. Politik Dan Birokrasi: Masalah Netralitas Birokrasi Di Indonesia Era Reformasi. Jurnal Review Politik. 6(1): 2-4.

Apter, David E. 1985. Pengantar Analisa Politik. LP3ES, Jakarta. HIm. 371.

Dalam artikel "Kabinet Parkinson" yang diunggah melalui laman web http://nasional.kompas.com.

Fajar Kuala Nugraha. 2017. Model Birokrasi Parkinson Dalam Pemerintahan Susilo Bambang Yudhoyono (SBY). Jurnal Transformative. 3(1):1-13.

Dina Fadiyah, Ummi Zakiyah. 2018. Menguatnya Iktan Patronase Dalam Perpolitikan Indonesia. Madani Jurnal Politik dan Sosial Kemasyarakatan. 10(2):1-14. 